\title{
Future Impact of Current Toll-Gates on the Capacity of the Southern Expressway
}

\author{
M. L. G. D. Kumari, P. G. D. Priyadarshana and \\ K. S. Weerasekera* \\ Department of Civil Engineering, The Open University of Sri Lanka
}

\begin{abstract}
The Southern Expressway plays a vital role in national road network in Sri Lanka. Vehicles on Expressways can travel at uniform speeds throughout their journey offering advantages on fuel consumption and reduced travel time. The expressways ensure a hassle free safe journey due to the minimum obstructions to the traffic.
\end{abstract}

At present, all the interchanges along the Southern Expressway operate with manually operated toll gates. The efficiency of current toll gates was studied for the existing exit ramp lengths and it investigated whether their current efficiencies are sufficient for higher vehicle volume of the future traffic. To investigate the current toll gate efficiency on the capacity of Southern Expressway, the necessary data were collected from relevant organizations. From the collected data, peak days and peak hours were identified for each and every exit ramp of the Southern Expressway. By considering the peak hours, critical exit ramps were identified. After identifying critical exit ramps of the interchanges, traffic studies were conducted to obtain arrival and service rates in peak hours during the peak days. Then, after analyzing survey data, maximum queue lengths and longest individual delays for critical exit ramps along the Southern Expressway were found. Simultaneously the analysis was carried-out for a different number of gates.

Finally, maximum queue lengths and longest individual delays were compared with existing ramp lengths, and shortcomings were identified. By using suitable growth rates for the Southern

\footnotetext{
*Correspondence should be addressed to Prof. K.S. Weerasekera, Department of Civil Engineering, Faculty of Engineering Technology, The Open University of Sri Lanka, Nawala, Sri Lanka.

(Email: kolitaw@gmail.com)
} 
Expressway, future traffic conditions were predicted. Subsequently, by using the maximum vehicular queue lengths, individual delays that could occur in the future were computed. Hence, these values were used to analyze the effect of the capacity of Southern Expressway due to the present toll gate arrangement. Therefore, it was able to recommend suitable off ramp lengths considering queue lengths and deceleration lengths. Recommendations were also proposed for future improvements to the service rates at toll gates.

Keywords: Southern Expressway, Service time, Service rate, Toll gates, Maximum queue length, Exit ramp length

\section{Introduction}

The Southern Expressway is the first expressway to be built in Sri Lanka and it is an important link of the proposed expressway network. It traverses from Kottawa to Matara $(126 \mathrm{~km})$ and the construction of the section from Kottawa to Pinnaduwa (Galle) was completed and operates as a dual carriageway expressway with 4lane facility when the study was conducted in 2013. Expressways have many advantages such as; reduced travel time, reduced traffic congestion, reduced transport delay costs, reduced fuel costs, attract private sector investors and thereby contribute to expand the job market and develop fisheries, agriculture, industries in the region, expand tourism presently confined to the coastal belt along Colombo-Galle-Matara, and enhance the value of land and property.

In the Southern Expressway (between Kottawa and Galle) there are eight interchanges namely; Kottawa (Makumbura), Kahathuduwa, Gelanigama, Dodangoda, Welipanna, Kurundugahahatakma, Baddegama, and Pinnaduwa (Galle).

\section{Problem Identification}

With the increase in traffic in the future, the possible formation of traffic queues at entry or exit points during congested periods can cause a considerable time delay and may result in the reduction of highway performance. Southern Expressway has shortened the journey time from Galle to Colombo to one hour. At present, since manually operated toll gates are installed and with increased traffic, it is intended to observe whether their efficiency is adequate to handle higher vehicle volumes. 


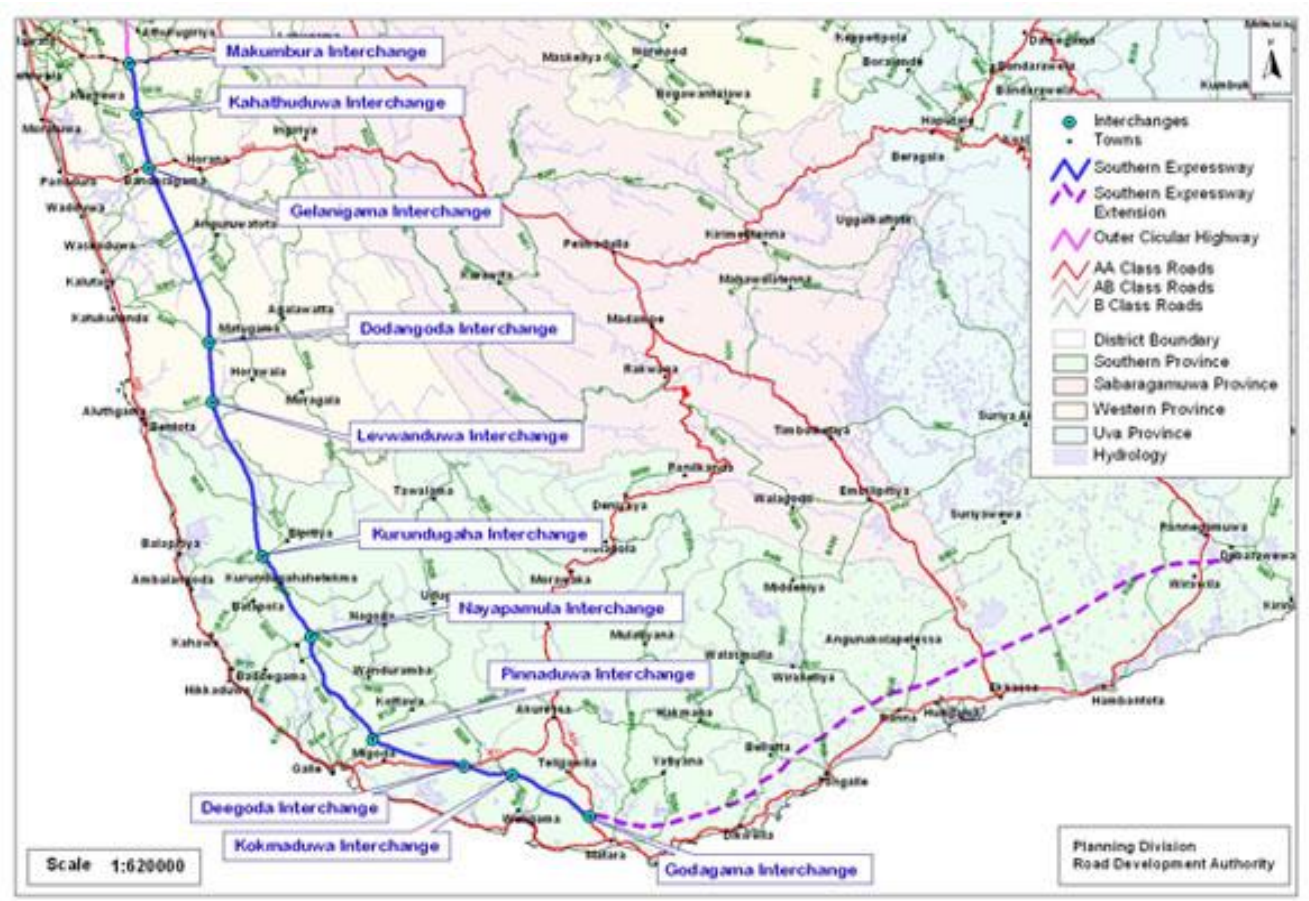

(Source: www:rda:gov:lk/supported/expressways/stdp:htlm)

Figure 1. Southern Expressway

At present, the traffic at the toll booths is not very heavy, but in future, with the increase of vehicles, the traffic at the booths could be a problem. Traffic delay in a toll plaza is caused by time taken due to the manual operated method adopted in paying user fee. Hence the long queues that could occur at exit ramps may cause safety threat to the vehicles travelling along the expressway if vehicles at toll booths heads-up along the exit ramps and enter the expressway. Therefore, in here, it studies the present toll gates operation and observes whether it could cope with future traffic needs at a meaningful level of service and investigates whether the capacity is adequate to meet this demand.

\section{Aim of the Study}

Aim of this study is to firstly investigate the efficiency of manually operated toll gates along the Southern Expressway and secondly to observe the impact on the capacity of interchanges which may finally limit the expressway potential in the future. 


\section{Objectives}

The objective of this study is to investigate the impact of toll gates efficiency on the capacity of Southern Expressway. It consists of investigating the present condition in interchanges, and to develop recommendations for future implementation (including traffic engineering, geometric consideration and benefit evaluations). These objectives entail the following:

Identify the critical interchanges in the road from Kottawa to Galle exit.

D Find any inefficiency at toll gates when operated manually.

$>$ Study ramp sufficiency and head-up length with future traffic.

$>$ Check the off ramp length according to deceleration length with possible formation queues in critical exit ramps.

$>$ If there are delays at toll booths, to investigate whether it will affect the free flow of the Southern Expressway.

Propose suitable tolling systems to cope with the future traffic needs if there are any delays due to toll gates causing a reduction in the capacity of the expressway.

\section{Strategies}

To achieve the aims of this project, following strategies and principles were used:

$>$ The layout arrangements of interchanges were studied in detail.

$>$ The number of entrance and exit gates was identified for all interchanges.

$>$ The exit ramp lengths were measured and the geometry of the intersection was studied for all interchanges.

$>$ Existing procedure of paying of user fee in toll gates and the toll gate operation was studied.

$>$ Peak day/peak hour was identified for each interchange.

$>$ The critical exit ramps of the expressway by considering exit ramp distances and traffic volume, were identified.

After identifying the peak days, traffic studies were conducted to obtain arrival rate and service rate for critical exit ramps in each interchange.

$>$ The graphs which indicate the arrival curve and service curve at different toll gates were plotted according to the survey data.

$>$ The longest individual delay and maximum queue were identified using above graphs for each critical exit ramps. 
By using the above graphs and collected data, the effects of the capacity of Southern Expressway due to present toll gates in interchanges, were analyzed.

Suitable off ramp lengths considering queue length and deceleration lengths were recommended and future improvements to the service rates at toll gates are suggested.

\section{Methodology}

\section{Graph of Time vs Cumulative Vehicle at Ramp}

Figure 2 illustrates the curve of Time vs. Cumulative Number of Vehicle and how it effects with service rate. The two curves shown in the Figure 2 is related arrival and service rates (Mannering and Washburn, 2004).

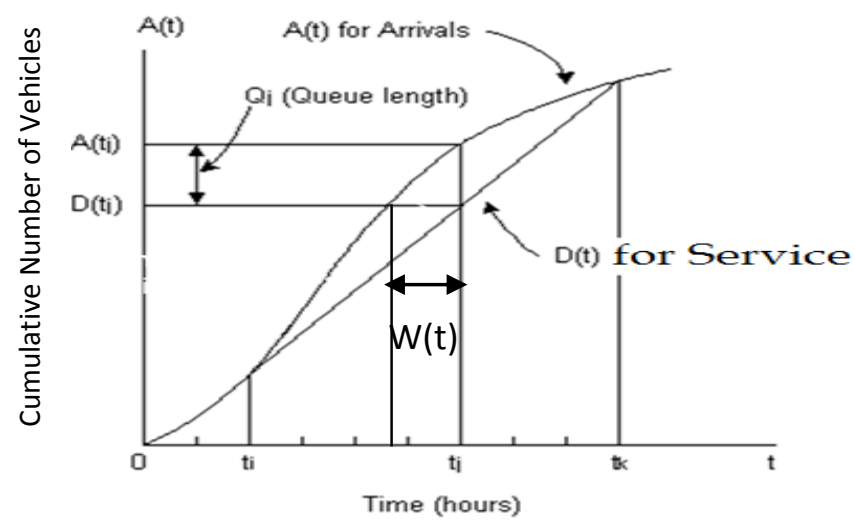

Figure 2. Graph of Cumulative Number of Vehicle vs. Time

Area between $\mathrm{A}(\mathrm{t})$ and $\mathrm{D}(\mathrm{t})$ represents the total delay, or summation of delay to all vehicles.

$\mathrm{Q}(\mathrm{t})$ - Vertical distance between $\mathrm{A}(\mathrm{t})$ and $\mathrm{D}(\mathrm{t})$ at any time $\mathrm{t}$, represents the numbers of vehicles in queue at that time $(\mathrm{t})$ Slope of $\mathrm{D}(\mathrm{t})$ in the 'departure rate'

Slope of $\mathrm{A}(\mathrm{t})$ in the 'arrival rate'

$\underline{\text { Note }}$

The departure rate cannot exceed the service rate or capacity of the service provider. Hence it has to be less.

Cumulative departure can never exceed cumulative arrivals. Hence $\mathrm{D}(\mathrm{t})$ can never be above $\mathrm{A}(\mathrm{t})$ in the queuing diagram. 
$>$ When queue is present the 'departure rate' will equal the 'service rate'.

$>$ The queue first forms when the 'arrival rate' first exceeds the service rates.

> $\mathrm{W}(\mathrm{t})$ Horizontal distance between $\mathrm{A}(\mathrm{t})$ and $\mathrm{D}(\mathrm{t})$ represents the delay to vehicle arriving at time $t$.

Service time - Service time of collection payment is the time between the entry of the vehicle into the toll booth until the exit of the vehicle from the toll booth.

Service rate - The number of vehicles serves in unit time

\section{Field Data}

The Southern Expressway consists of eight interchanges between Kottawa and Pinnaduwa including the two at the ends. They are of the following types:

$\begin{array}{ll}\text { Kottawa (Makumbura) } & \text { Grade separated } \\ \text { Kahathuduwa } & \text { Diamond (conventional) } \\ \text { Gelanigama } & \text { Partial cloverleaf } \\ \text { Dodangoda } & \text { Diamond (conventional) } \\ \text { Welipanna } & \text { Diamond (conventional) } \\ \text { Kurundugahahatakma } & \text { Partial cloverleaf (modified) } \\ \text { Baddegama } & \text { Diamond (conventional) } \\ \text { Pinnaduwa (Galle) } & \text { Mixed diamond- cloverleaf }\end{array}$

(Source: RDA, www.rda.gov.lk/supported/expressways/stdp.htlm)

\section{Adopted Procedure in Paying 'User Fee'}

When a driver enters the expressway, a ticket is issued to him/her at the entry toll gate of the interchange. The ticket displays the type of the vehicle (vehicle category), date, time and name of the interchange which the vehicle entered. Driver has to handover the ticket to the exit toll gate, and he/she will be informed of the user fee. A receipt will be issued for the payment of the user fee.

Due to the manual transaction, the operator has to monitor the entrance ticket details. Also, the user takes time to pay for the usage. Therefore, it takes time at exit toll gates compared with other advanced tolling methods. It was especially experienced when paying of fines for over speeding or any other negligence of road rules, causing further delay at exit gates. 


\section{Present Condition of Entry and Exit Gates}

It is not the same number of entry and exit gates that have been constructed in each interchange for the two directions. At present, only a few gates are operating due to lack of traffic. The gate details and exit ramp lengths are tabulated in Table 1.

Table 1. Number of entry and exit gates and exit ramp lengths of interchanges

\begin{tabular}{|c|c|c|c|c|c|c|}
\hline \multirow[t]{3}{*}{ Interchange } & \multicolumn{4}{|c|}{$\begin{array}{l}\text { Number of toll gates ( total } \\
\text { in both direction) }\end{array}$} & \multirow[t]{3}{*}{ Exit Ramp } & \multirow{3}{*}{$\begin{array}{c}\text { Exit } \\
\text { Ramp } \\
\text { length } \\
\text { (m) }\end{array}$} \\
\hline & \multicolumn{2}{|c|}{ Constructed } & \multicolumn{2}{|c|}{$\begin{array}{l}\text { Currently } \\
\text { operating }\end{array}$} & & \\
\hline & Entry & Exit & Entry & Exit & & \\
\hline $\begin{array}{l}\text { Kottawa } \\
\text { (Makumbura) }\end{array}$ & 05 & 08 & 02 & 03 & Ramp 1 - From Galle & 197 \\
\hline \multirow[t]{2}{*}{ Kahathuduwa } & \multirow[t]{2}{*}{04} & \multirow[t]{2}{*}{04} & \multirow[t]{2}{*}{02} & \multirow[t]{2}{*}{02} & Ramp 1 - From Galle & 106 \\
\hline & & & & & Ramp 2 - From Colombo & 96 \\
\hline \multirow[t]{2}{*}{ Gelanigama } & \multirow[t]{2}{*}{04} & \multirow[t]{2}{*}{04} & \multirow[t]{2}{*}{02} & \multirow[t]{2}{*}{02} & Ramp 1 - From Galle & 181 \\
\hline & & & & & Ramp 2 - From Colombo & 187 \\
\hline \multirow[t]{2}{*}{ Dodangoda } & \multirow[t]{2}{*}{04} & \multirow[t]{2}{*}{04} & \multirow[t]{2}{*}{02} & \multirow[t]{2}{*}{02} & Ramp 1 - From Galle & 93 \\
\hline & & & & & Ramp 2 - From Colombo & 134 \\
\hline \multirow[t]{2}{*}{ Welipanna } & \multirow[t]{2}{*}{04} & \multirow[t]{2}{*}{04} & \multirow[t]{2}{*}{02} & \multirow[t]{2}{*}{02} & Ramp 1 - From Galle & 73 \\
\hline & & & & & Ramp 2 - From Colombo & 69 \\
\hline \multirow{2}{*}{$\begin{array}{l}\text { Kurundugaha } \\
\text { hatakma }\end{array}$} & \multirow[t]{2}{*}{04} & \multirow[t]{2}{*}{04} & \multirow[t]{2}{*}{02} & \multirow[t]{2}{*}{02} & Ramp 1 - From Galle & 45 \\
\hline & & & & & Ramp 2 - From Colombo & 134 \\
\hline \multirow[t]{2}{*}{ Baddegama } & \multirow[t]{2}{*}{04} & \multirow[t]{2}{*}{04} & \multirow[t]{2}{*}{02} & \multirow[t]{2}{*}{02} & Ramp 1 - From Galle & 154 \\
\hline & & & & & Ramp 2 - From Colombo & 90 \\
\hline $\begin{array}{l}\text { Pinnaduwa } \\
\text { (Galle) }\end{array}$ & 02 & 02 & 01 & 02 & Ramp 1 - From Galle & 378 \\
\hline \multicolumn{7}{|c|}{ (Source: Expressway Operation Maintenance and Management Division - RDA) } \\
\hline
\end{tabular}

The study requires correctly identifying critical exit ramps since delays occur at exit ramps. Therefore, out of seventeen exit ramps between Kottawa and Pinnaduwa, critical exit ramps were identified using 'weight factor' as described below.

Method adopted for computation of 'weight factor' is based on ramp length, and peak hour volume. By observing traffic data during a 
period of one week, peak hour volumes for each interchange were identified. Then weight factor is obtained by dividing the peak hour volume of each exit ramp by the measured ramp length. The number of toll gates was considered when queue length exceeded the off ramp length.

Weight factor $\quad=\quad$ Peak hour volume (veh $/ \mathrm{hr})$ Ramp length (m)

Table 2. The weight factors for each interchange

\begin{tabular}{llccc}
\hline \multicolumn{1}{c}{ Interchange } & \multicolumn{1}{c}{ Exit Ramps } & $\begin{array}{c}\text { Peak hour } \\
\text { volume } \\
\text { ( veh/hr) }\end{array}$ & $\begin{array}{c}\text { Ramp } \\
\text { Distance } \\
(\mathbf{m})\end{array}$ & $\begin{array}{c}\text { Weight } \\
\text { factor } \\
(\mathbf{v e h} / \mathbf{m} / \mathbf{h r})\end{array}$ \\
\hline Kottawa & Ramp 1 - From Galle & 683 & 197 & $\mathbf{3 . 4 7}$ \\
\hline Kahathuduwa & Ramp 1 - From Galle & 75 & 106 & $\mathbf{0 . 7 1}$ \\
\cline { 2 - 5 } & Ramp 2 - From Colombo & 16 & 96 & 0.17 \\
\hline \multirow{2}{*}{ Galanigama } & Ramp 1 - From Galle & 94 & 181 & $\mathbf{0 . 5 2}$ \\
\cline { 2 - 5 } & Ramp 2 - From Colombo & 60 & 187 & 0.32 \\
\hline Dodangoda & Ramp 1 - From Galle & 41 & 93 & 0.44 \\
\cline { 2 - 5 } & Ramp 2 - From Colombo & 74 & 134 & $\mathbf{0 . 5 5}$ \\
\hline \multirow{2}{*}{ Welipanna } & Ramp 1 - From Galle & 23 & 73 & 0.31 \\
\cline { 2 - 5 } & Ramp 2 - From Colombo & 58 & 69 & $\mathbf{0 . 8 3}$ \\
\hline \multirow{2}{*}{ Kurundugahahathak } & Ramp 1 - From Galle & 24 & 45 & $\mathbf{0 . 5 3}$ \\
\cline { 2 - 5 } ma & Ramp 2 - From Colombo & 55 & 134 & 0.41 \\
\hline Baddegama & Ramp 1 - From Galle & 9 & 154 & 0.06 \\
\cline { 2 - 5 } & Ramp 2 - From Colombo & 43 & 90 & 0.48 \\
\hline Pinnaduwa & Ramp 1 - From Colombo & 257 & 378 & $\mathbf{0 . 6 8}$ \\
\hline
\end{tabular}

\section{Selection of Critical Exit Ramps}

According to the weight factors shown in Table 2, seven critical exit ramps were selected to conduct the detailed surveys. Exit ramps consisting of weight factors above 0.5 were considered as critical exit ramps. This was to limit the number of ramps to be studied, rather than studying all the ramps. Hence, at-least one exit ramp was selected from all the interchanges except Baddegama (see Table 2).

\section{Selection of field survey days (as per data collected from RDA)}

Prior to conducting traffic survey at the interchanges, probable peak days and peak hours for exit ramps were identified according to collected data from Expressway Operation Management and 
Maintenance division of RDA. These traffic survey days and time periods are as shown in Table 3.

Table 3. The peak hour ranges for each critical exit ramps

\begin{tabular}{llll}
\hline Interchange & Day & Date & Time period (hrs) \\
\hline Kottawa & Monday (Poya day) & $\begin{array}{l}25.03 .2013- \\
26.03 .2013\end{array}$ & $16: 00-06: 00$ \\
\hline Kahathuduwa & Sunday & 07.04 .2013 & $17: 00-21: 00$ \\
\hline Galenigama & Sunday & 21.04 .2013 & $16: 00-19: 00$ \\
\hline Dodangoda & Sunday & 21.04 .2013 & $11: 00-17: 00$ \\
\hline Welipanna & Sunday & 28.04 .2013 & $11: 00-17: 00$ \\
\hline Kurundugahahetakma & Sunday & 28.04 .2013 & $13: 00-17: 00$ \\
\hline Pinnaduwa & Saturday & 04.05 .2013 & $09: 00-17: 00$ \\
\hline
\end{tabular}

\section{Present Condition of Toll Gates Considering Average Service Time}

Separate surveys were conducted for each and every gate operating in critical exit ramps. The survey durations are as indicated in Table 3 . The purpose of the survey was to obtain the average service time in each toll gate according to the exit ramps.

Table 4. The average service time for each gate

\begin{tabular}{|l|c|c|c|}
\hline \multicolumn{1}{|c|}{ Interchange } & $\begin{array}{c}\text { Exit gate } \\
\text { No. }\end{array}$ & $\begin{array}{c}\text { Average service time } \\
\text { for each gate (seconds) }\end{array}$ & $\begin{array}{c}\text { Average service } \\
\text { time for each } \\
\text { interchange } \\
\text { (seconds) }\end{array}$ \\
\hline Kottawa & 1 & 15.83 & 17.86 \\
& 2 & 16.37 & \\
\hline Kahathuduwa & 1 & 22.07 & 25.45 \\
\hline Galanigama & 1 & 25.45 & 17.13 \\
\hline Dodangoda & 1 & 17.13 & 19.09 \\
\hline Welipanna & 1 & 19.09 & 19.00 \\
\hline Kurundugahahatakma & 1 & 19.00 & 15.75 \\
\hline Pinnaduwa & 1 & 15.75 & 15.42 \\
\hline \multicolumn{2}{|c|}{ Average service time (seconds) } \\
\hline
\end{tabular}

Time at the commencement of service and departure for each vehicle was recorded. The difference of departure time and service commencing time for each vehicle was used to calculate service time. 
Service time was calculated separately for each interchange, then considering all the interchanges the average service time for current tolling system (manual operation method) was computed and tabulated in Table 4.

\section{Average Length for Vehicle Categories}

Traffic on interchanges is mixed in nature. Therefore, several categories (according to Southern Expressway Operation Maintenance and Management division) were selected to calculate queue lengths. Average lengths of vehicles are as shown in Table 5.

Table 5. Average vehicle length

\begin{tabular}{clc}
\hline $\begin{array}{c}\text { Vehicle } \\
\text { category }\end{array}$ & \multicolumn{1}{c}{ Description } & $\begin{array}{c}\text { Average } \\
\text { length (m) }\end{array}$ \\
\hline A & Car, utility vehicles, light good vehicles & 4.92 \\
B & $\begin{array}{l}\text { Medium / large buses, larger lorries/ } \\
\text { trucks }\end{array}$ & 10.9 \\
\hline C & 3 Axels vehicle & 12.5 \\
\hline D & More than 3 Axels vehicle & 16
\end{tabular}

(Source: Washington States Department of Transportation, 2011)

Four wheel drive jeeps, small trucks with design on a car frame and vans come under utility vehicles and light good vehicles.

The average length of car $(4.92 \mathrm{~m})$ was selected for all the vehicles included in category 'A'. It was selected based on the highest composition according to field survey data. The average length of a large bus $(10.9 \mathrm{~m})$ was selected for all the vehicles included in category 'B'. It was selected based on the highest composition according to field survey data.

\section{Traffic Volume Data up to 2080 Using Trend Curves}

Trend curves were drawn up to year 2080 according to predicted vehicle growth rates for Southern Expressway from RDA. The obtained values are given in Table 6 . 
Table 6. Predicted vehicle growth

\begin{tabular}{|c|c|c|c|c|c|c|c|c|c|c|c|c|c|c|c|}
\hline \multirow{2}{*}{$\begin{array}{l}\text { Intercha } \\
\text { nge }\end{array}$} & \multirow{2}{*}{$\begin{array}{l}\text { Vehicle } \\
\text { category }\end{array}$} & \multicolumn{14}{|c|}{ Predicted vehicle growth (\%) } \\
\hline & & 亏ે & స్ & 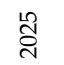 & ণ్రి & 号 & 总 & 㝵 & గి & 总 & 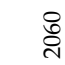 & 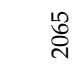 & ปั & $\stackrel{\text { co }}{\circ}$ & \\
\hline \multirow[t]{4}{*}{$\begin{array}{l}\text { Kottawa, } \\
\text { Kahathudu } \\
\text { wa, } \\
\text { Galanigama }\end{array}$} & $\begin{array}{l}\text { Car, utility } \\
\text { vehicles, } \\
\text { light good } \\
\text { vehicles } \\
\text { (A) }\end{array}$ & 6.3 & 5.1 & 3.6 & 4.1 & 3.95 & 3.8 & 3.7 & 3.6 & 3.5 & 3.45 & 3.4 & 3.3 & 3.25 & 3.2 \\
\hline & $\begin{array}{l}\text { M/L } \\
\text { buses, L } \\
\text { lorries / } \\
\text { trucks (B) }\end{array}$ & 2.9 & 2.3 & 2.1 & 2.21 & 2.19 & 2.12 & 2.11 & 2.1 & 2.0 & 2.04 & 2.01 & 2 & 1.99 & 1.95 \\
\hline & $\begin{array}{l}3 \text { Axels } \\
\text { vehicle (C) }\end{array}$ & 2.9 & 2.3 & 2.1 & 2.05 & 1.93 & 1.8 & 1.7 & 1.6 & 1.5 & 2.06 & 1.32 & 1.22 & 1.15 & 1.11 \\
\hline & $\begin{array}{l}\text { More than } \\
3 \text { Axels } \\
\text { vehicle (D) }\end{array}$ & 6.3 & 6.5 & 3.8 & 4.21 & 3.82 & 3.5 & 3.25 & 2.95 & 2.7 & 2.5 & 2.25 & 2.05 & 1.86 & 1.7 \\
\hline \multirow[t]{4}{*}{$\begin{array}{l}\text { Dodangoda } \\
\text { Welipanna, } \\
\text { Kurunduga } \\
\text { hahatakma, } \\
\text { Baddegama } \\
\text { Pinnaduwa }\end{array}$} & $\begin{array}{l}\text { Car, utility } \\
\text { veh., light } \\
\text { good veh. } \\
\text { (A) }\end{array}$ & 11.2 & 9.8 & 6.8 & 8.2 & 8.1 & 8 & 7.9 & 7.8 & 7.8 & 7.7 & 7.6 & 7.58 & 7.56 & 7.5 \\
\hline & $\begin{array}{l}\text { M/L } \\
\text { buses, L } \\
\text { lorries / } \\
\text { trucks (B) }\end{array}$ & 5.2 & 4.5 & 3.9 & 4.41 & 4.46 & 4.5 & 4.51 & 4.52 & 4.5 & 4.55 & 4.58 & 4.59 & 4.59 & 4.6 \\
\hline & $\begin{array}{l}3 \text { Axels } \\
\text { vehicle }(C)\end{array}$ & 11.3 & 12.5 & 7.3 & 9 & 8.6 & 8.3 & 8.1 & 7.9 & 2.6 & 7.3 & 7.1 & 6.9 & 6.65 & 6.4 \\
\hline & $\begin{array}{l}\text { More than } 1 \\
3 \text { Axels } \\
\text { vehicle (D) }\end{array}$ & & 12.5 & 7.3 & 8.9 & 8.6 & 8.3 & 8.1 & 7.8 & 7.6 & 7.4 & 7.1 & 6.9 & 6.7 & 6.45 \\
\hline
\end{tabular}

\section{Data Analysis}

\section{Traffic Volume Forecast of Southern Expressway}

Traffic volume forecast data were used to calculate the annual traffic growth rates for vehicle categories. And the equation which was used to calculate the future traffic demand was stated below (Mannering and Kilareski, 1998). 
$($ Peak hour volume $)$ future $=($ Peak hour volume $)$ present $\times(1+g)^{n}$ $\mathrm{g}=$ Annual growth rate $\mathrm{n}=$ Number of year

Above equation and relevant annual traffic growth rates were used to calculate the peak hour volume in coming years.

Example: Sample calculation for Kottawa interchange at 2017 (i.e. 4 years from 2013)

$(\text { Peak hour volume })_{2017}=(\text { Peak hour volume })_{2013} \times(1+g) n$

$(\text { Peak hour volume })_{2017}=554 \times(1+0.063)^{4}=704 \mathrm{veh} / \mathrm{hr}$

Calculated vehicle growth over the years for Kottawa interchange is tabulated below in Table 7 . The same procedure was followed to calculate vehicle growth for other interchanges as well.

Table 7. Vehicle growth at Kottawa interchange over the years

\begin{tabular}{|c|c|c|c|c|c|c|c|c|c|c|c|c|c|c|c|}
\hline \multirow[t]{2}{*}{ Time } & \multicolumn{15}{|c|}{ Cumulative Number of Vehicles } \\
\hline & $\stackrel{\mathscr{D}}{0}$ & $\stackrel{\nabla}{\widetilde{d}}$ & ิㅗㅇ & 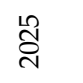 & గ్రి & ஜิ & 융 & 원 & $\begin{array}{l}\stackrel{ }{0} \\
\stackrel{ }{0}\end{array}$ & ํํํ & ঠ̊ঠి & 용 & 尺્ત & 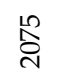 & $\begin{array}{l}\text { \& } \\
\stackrel{\text { సे }}{ }\end{array}$ \\
\hline 16:00-16:05 & 25 & 32 & 41 & 45 & 55 & 66 & 80 & 96 & 114 & 135 & 160 & 189 & 222 & 260 & 304 \\
\hline 16:05-16:10 & 51 & 64 & 82 & 91 & 111 & 134 & 160 & 191 & 228 & 269 & 318 & 375 & 440 & 515 & 602 \\
\hline 16:10-16:15 & 80 & 101 & 129 & 143 & 174 & 211 & 253 & 303 & 360 & 427 & 504 & 595 & 698 & 818 & 956 \\
\hline 16:15-16:20 & 119 & 151 & 192 & 213 & 260 & 314 & 377 & 451 & 537 & 636 & 752 & 887 & 1041 & 1220 & 1425 \\
\hline $16: 20-16: 25$ & 163 & 207 & 263 & 292 & 356 & 431 & 517 & 619 & 737 & 873 & 1033 & 1218 & 1430 & 1676 & 1958 \\
\hline $16: 25-16: 30$ & 215 & 273 & 348 & 386 & 470 & 569 & 684 & 818 & 974 & 1154 & 1365 & 1611 & 1892 & 2216 & 2591 \\
\hline $16: 30-16: 35$ & 263 & 334 & 425 & 472 & 575 & 696 & 836 & 1000 & 1190 & 1410 & 1669 & 1968 & 2311 & 2708 & 3166 \\
\hline $16: 35-16: 40$ & 311 & 395 & 504 & 559 & 681 & 824 & 991 & 1185 & 1411 & 1673 & 1979 & 2335 & 2743 & 3214 & 3757 \\
\hline $16: 40-16: 45$ & 371 & 471 & 601 & 667 & 813 & 984 & 1183 & 1415 & 1686 & 1998 & 2365 & 2791 & 3278 & 3841 & 4491 \\
\hline $16: 45-16: 50$ & 429 & 545 & 696 & 772 & 941 & 1140 & 1370 & 1640 & 1954 & 2316 & 2741 & 3235 & 3801 & 4454 & 5208 \\
\hline 16:50-16:55 & 494 & 628 & 802 & 890 & 1085 & 1314 & 1580 & 1892 & 2254 & 2673 & 3163 & 3734 & 4387 & 5142 & 6013 \\
\hline 16:55-17:00 & 554 & 704 & 900 & 999 & 1219 & 1476 & 1776 & 2126 & 2533 & 3005 & 3557 & 4199 & 4934 & 5783 & 6764 \\
\hline 17:00-17:05 & 624 & 793 & 1014 & 1126 & 1373 & 1663 & 2001 & 2395 & 2854 & 3386 & 4007 & 4731 & 5559 & 6517 & 7622 \\
\hline
\end{tabular}

In order to identify the efficiency of current toll gates for present and future conditions, the following study methodology was adopted.

Service rate when operating a different number of toll gates.

(Service rate denotes the rate at which vehicles are being served in a system. In here service rate depends on the number of toll booths and average service time.) 
As indicated in Banks (2010), service rate when operating of different number of toll gates;

Service rate $=[1$ vehicle $\times 60 \times$ No. of toll booths $\times$ Time interval for arrival rate (veh/min)] / Average service time

According to the queuing analysis graph of time vs. cumulative number of vehicles, following terms are indicated.

- Number of vehicle in queue

- Individual delay time

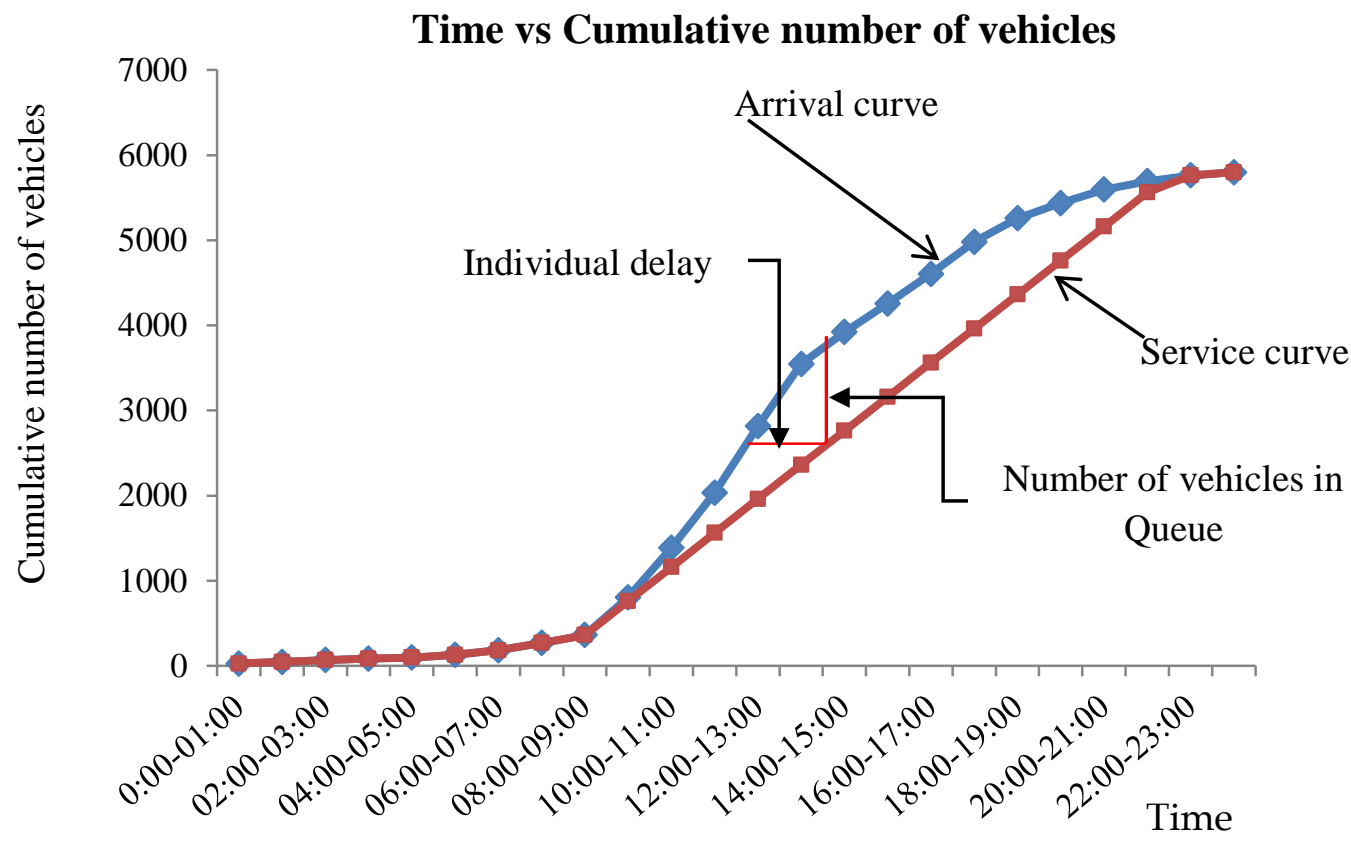

Figure 3. Graph of time vs. cumulative number of vehicles

Critical exit ramps were evaluated to see whether they could handle the present traffic flow according to the traffic survey results. Figure 3 illustrates variation of time vs. cumulative number of vehicles at Pinnaduwa. In here, these two curves represent arrival curve and service curve. Arrival curve was plotted according to the 5 minutes time interval during the peak hours at each exit ramp. Service rates were calculated for different number of toll gates when operating at exit ramps. Service curve was plotted according to the number of toll gates in operating. Vertical length between these two curves indicates 
the number of vehicles in queue and horizontal difference indicates individual delay.

\section{Service Rate, When Operating Different Number of Toll Gates for 5 Minute Arrival Rate}

Service rate $=[1$ vehicle $\times 60 \times$ No. of toll booths $\times$ Time interval for arrival rate (veh/min)] / Average service time

Sample calculation for service rate when operating one toll gate only;

Service rate $=[1 \times 60 \mathrm{~s} \times 1 \times 5 \mathrm{~s}] / 18 \mathrm{~s} / \mathrm{veh}$

$$
=\underline{\underline{16.67 \mathrm{veh} / 5 \mathrm{~min}}}
$$

Service rate increases due to the number of gates operating in exit ramps. Table 8 shows service rates for 5 minutes time duration for a different number of toll gates.

Kottawa interchange has the most number of exit gates. It has eight exit gates. It is observed that more vehicles can be served when the number of toll gates increase. When operating one gate, seventeen vehicles can be served in 5 minutes. As observed in Table 8 with the increase of number of gates, number of vehicles served in exit ramps too increases.

Table 8. Service rates

\begin{tabular}{cc}
\hline Number of toll gates & Service rate ( veh / 5 min ) \\
\hline 1 & 16.67 \\
2 & 33.33 \\
3 & 50 \\
5 & 66.67 \\
6 & 83.33 \\
7 & 100 \\
8 & 116.67 \\
\hline
\end{tabular}




\section{Analysis of Maximum Queue Length and Individual Delay Time Up to Year 2080 when Operated Different Number of Toll Gates}

Sample 1 - Maximum queue length and maximum individual delay at Kottawa interchange

Survey data were used to obtain the cumulative number of vehicles. Arrival curve was obtained when plotting cumulative number of vehicles against time. Service curves were also plotted according to the number of gates in service and it varies with time. For the purpose of identification of future traffic, arrival curves were also plotted according to predicted vehicle growth.

Kottawa Interchange-Exit Ramp (exit of vehicles arriving from Galle)-When one gate is operating

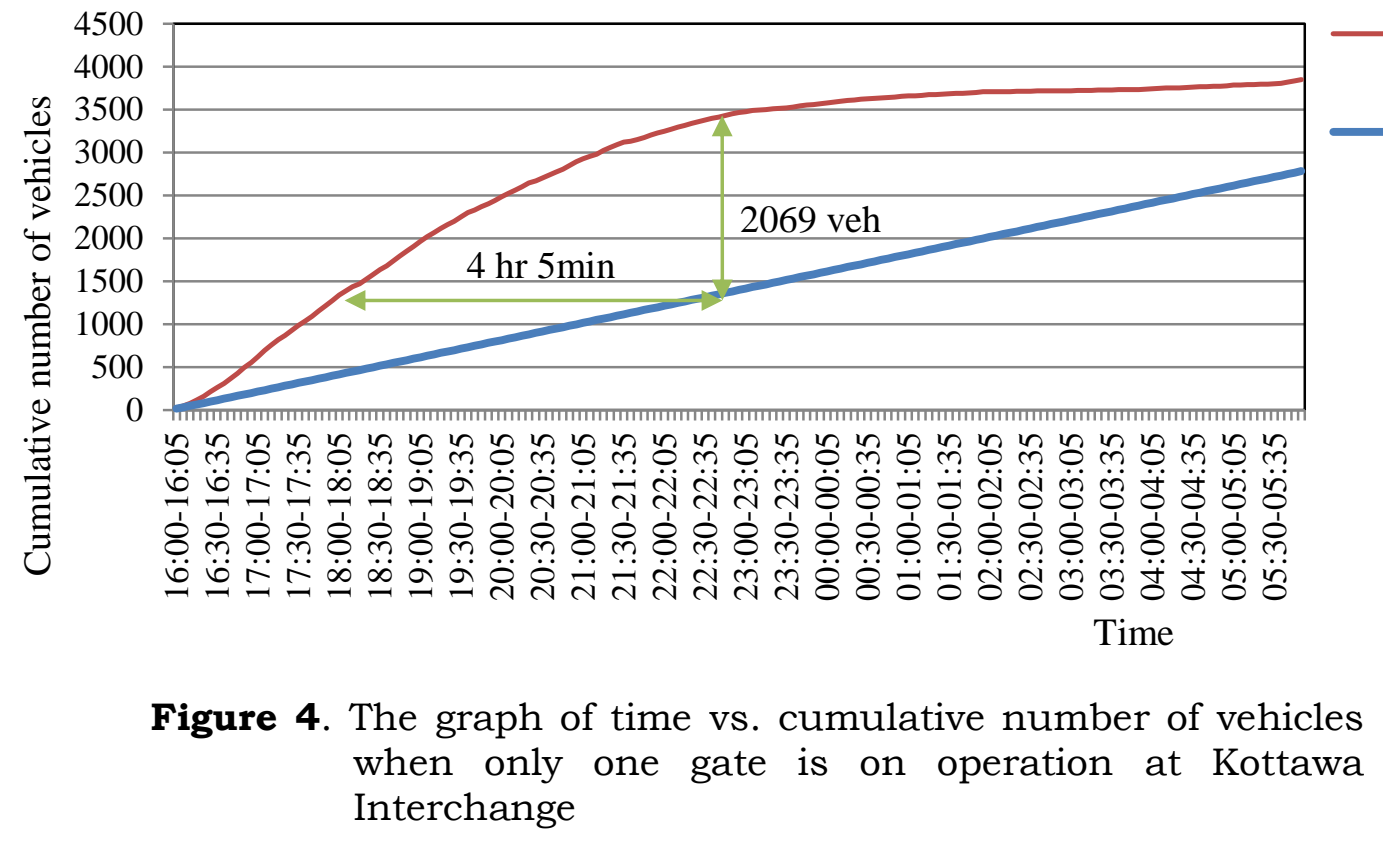

The total length of the queue at a specified time, expressed by the number of vehicles, is given for the particular exit ramp from the vertical length between arrival and departure curves. It shows the longest vehicle queue at manual system when only one gate is in operation. The longest vehicle queue occurs at time 22:50 hrs consisting of 2069 vehicles. 


\section{Sample Calculation for Present Condition When Only One Gate is on Operation at Kottawa Interchange}

For the calculation of maximum longest queue for that particular exit ramp, average vehicle length according to the anticipated vehicle composition was found. One meter gap in between two successive vehicles was assumed.

Maximum no. of vehicle in queue at present $=2069$ veh

Average vehicle length $=\sum$ (Percentage composition for vehicle category $\times$ Average length of vehicle category)

Average vehicle length $=(92.43 \% \times$ Average length of category A $)$ $+(4.91 \% \times$ Average length of category B) $+(1.56 \% \times$ Average length of category $\mathrm{C})+(1.1 \% \times$ Average length of category D)

$=(92.43 \% \times 4.92 \mathrm{~m})+(4.91 \% \times 10.9 \mathrm{~m})+$ $(1.56 \% \times 12.5 \mathrm{~m})+(1.1 \% \times 16 \mathrm{~m})$

$=5.45 \mathrm{~m}$

Gap between two successive vehicles $=1 \mathrm{~m}$

Maximum queue length at present $=$ Maximum No. of vehicle in queue at present $x$ (Average vehicle length + Gap between successive vehicle)

$=2069 \times(5.45+1) \mathrm{m}$

Longest individual delay

$=13345 \mathrm{~m}$

$=4 \mathrm{hr} 5 \mathrm{~min}$

At present it was found that $13345 \mathrm{~m}$ queue length is the longest queue length if only one gate at Kottawa exit ramp is in operation. When the operating gates are increased the queue length will decrease proportionally. Since critical exit ramp length of Kottawa interchange is only $197 \mathrm{~m}$, it will be insufficient even with more gates operating at present service rates.

The same procedure was followed in obtaining maximum queue length and longest individual delay for each interchange when operating at different number of toll gates up to 2080 for critical exit ramps at interchanges. 


\section{Deceleration Lane Length}

Exit ramp design based on the assumption that vehicles exiting from a freeway have adequate space to decelerate to the ramp's limiting design speed feature (typically a horizontal curve) after clearing the through traffic lane. The length provided between the freeway departure point and the ramp's limiting design speed feature should be at least as long as the distance needed to accomplish the appropriate deceleration which is governed by the speed of traffic on the through lane and the speed to be attained on the ramp.

\section{Calculation of Minimum Deceleration Lane Length for Exit Ramps}

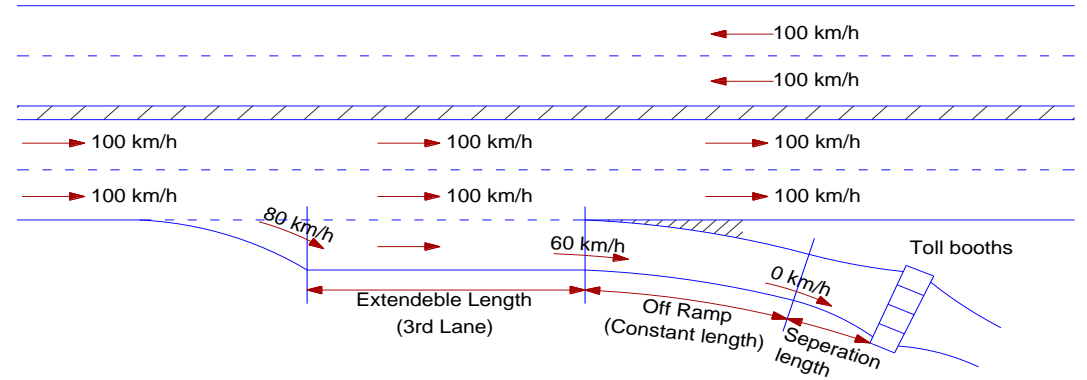

Figure 5. Deceleration lane of off ramp

$\begin{array}{ll}\text { Lower limit of highway design speed } & =80 \mathrm{kmph} \\ \text { Design speed of off ramps } & =60 \mathrm{kmph}\end{array}$

The recommended minimum deceleration lane length for an off ramp is $255 \mathrm{ft}(77.7 \mathrm{~m})$ when vehicle travels at $80 \mathrm{kmph}$ to become $60 \mathrm{kmph}$ and once it reaches that speed the vehicle needs further $300 \mathrm{ft}(91.4 \mathrm{~m})$ lane length to stop the vehicle. Those values are clearly indicated in Table 9 considering highway design speed of the Southern Expressway.

Also it needs to provide deceleration lane length to the end of the anticipated queue at the off ramps. In here minimum deceleration length was considered as per Washington State Department of Transportation (WSDOT) Design manual 2011. 
Table 9. Minimum Deceleration Lane Length

\begin{tabular}{|c|c|c|c|c|c|c|c|c|c|c|c|c|c|}
\hline \multirow{2}{*}{$\begin{array}{c}\text { Highway } \\
\text { Design } \\
\text { Speed } \\
\text { (mph) }\end{array}$} & \multirow{2}{*}{$\begin{array}{l}\text { Highway } \\
\text { Design } \\
\text { Speed } \\
\text { (kmph) }\end{array}$} & \multicolumn{12}{|c|}{ Minimum deceleration lane length (ft) for ramp design speed (mph) } \\
\hline & & 0 & 15 & 20 & 25 & 30 & 35 & 37.5 & 40 & 45 & 50 & 60 & 70 \\
\hline 30 & 48 & 235 & 200 & 170 & 140 & & & & & & & & \\
\hline 35 & 56 & 280 & 250 & 210 & 185 & 150 & & & & & & & \\
\hline 37.5 & 60 & 300 & & & & & & & & & & & \\
\hline 40 & 64 & 320 & 295 & 265 & 235 & 185 & 155 & & & & & & \\
\hline 45 & 72 & 385 & 350 & 325 & 295 & 250 & 220 & & 155 & & & & \\
\hline 50 & 80 & 435 & 405 & 385 & 355 & 315 & 285 & 255 & 225 & 175 & & & \\
\hline 55 & 88 & 480 & 455 & 440 & 410 & 380 & 350 & & 285 & 235 & 180 & & \\
\hline 60 & 96 & 530 & 500 & 480 & 460 & 430 & 405 & & 350 & 300 & 240 & & \\
\hline 65 & 104 & 570 & 540 & 520 & 500 & 470 & 440 & & 390 & 340 & 280 & 185 & \\
\hline 70 & 112 & 615 & 590 & 570 & 550 & 520 & 490 & & 440 & 390 & 340 & 240 & \\
\hline \multirow[t]{2}{*}{80} & 128 & 735 & 710 & 690 & 670 & 640 & 610 & & 555 & 510 & 465 & 360 & 265 \\
\hline & & 0 & 24 & 32 & 40 & 48 & 56 & 60 & 64 & 72 & 80 & 96 & 112 \\
\hline
\end{tabular}

(Source: WSDOT Design Manual 2011 - Chapter 1360)

Minimum deceleration lane length to achieve $60 \mathrm{~km} / \mathrm{h}$ (ramp design speed), when vehicle travels lower highway design speed of $80 \mathrm{~km} / \mathrm{h}$ for exit ramps is;

Minimum deceleration lane length $=255 \mathrm{ft}(78 \mathrm{~m})$

Minimum deceleration lane length, once the vehicle achieves 60 $\mathrm{km} / \mathrm{h}$ (i.e. ramp design speed) to stop the vehicle.

Minimum deceleration lane length $\quad=300 \mathrm{ft}$

Total Minimum deceleration lane length $=255 \mathrm{ft}+300 \mathrm{ft}$

$$
=\underline{\underline{555 \mathrm{ft}(170 \mathrm{~m})}}
$$

Therefore, total minimum deceleration lane length should be $170 \mathrm{~m}$ for all exit ramps. 
The calculated minimum deceleration lane length for an off ramp is 170 meters. Exsisting ramp length of Kahathuduwa ramp 1 (from Galle) and ramp 2 (from Colombo), Dodangoga ramp 1 (from Galle) and ramp 2 (from Colombo), Welipanna ramp 1 (from Galle) and ramp 2 (from Colombo), Kurundugahahatakma ramp 1 (from Galle) and ramp 2 (from Colombo), Baddegama ramp 1 (from Galle) and ramp 2 (from Colombo) are respectively $106 \mathrm{~m}, 96 \mathrm{~m}, 93 \mathrm{~m}, 134 \mathrm{~m}, 73 \mathrm{~m}, 69 \mathrm{~m}, 45 \mathrm{~m}, 134 \mathrm{~m}, 154 \mathrm{~m}$, and $90 \mathrm{~m}$. Therefore, Table 10 highlights the exit ramps which do not satisfy the minimum deceleration lane length of 170 meter requirement according to WSDOT design Manual 2011.

Table 10. Comparison of minimum deceleration lane length and existing exit ramp lengths

\begin{tabular}{|c|c|c|c|}
\hline Interchange & Exit ramps & $\begin{array}{l}\text { Ramp } \\
\text { length } \\
(\mathbf{m})\end{array}$ & $\begin{array}{l}\text { Minimum } \\
\text { deceleration } \\
\text { lane length }\end{array}$ \\
\hline Kottawa & Ramp 1 - From Galle & 197 & \multirow{3}{*}{$\begin{array}{c}\text { (Satisfy) } \\
\text { (Do not satisfy) } \\
\text { (Do not satisfy) }\end{array}$} \\
\hline \multirow[t]{2}{*}{ Kahathuduwa } & Ramp 1 - From Galle & 106 & \\
\hline & Ramp 2 - From Colombo & 96 & \\
\hline \multirow[t]{2}{*}{ Galenigama } & Ramp 1 - From Galle & 181 & \multirow{2}{*}{$\begin{array}{l}\text { (Satisfy) } \\
\text { (Satisfy) }\end{array}$} \\
\hline & Ramp 2 - From Colombo & 187 & \\
\hline \multirow[t]{2}{*}{ Dodangoda } & Ramp 1 - From Galle & 93 & \multirow{4}{*}{$\begin{array}{l}\text { (Do not satisfy) } \\
\text { (Do not satisfy) } \\
\text { (Do not satisfy) } \\
\text { (Do not satisfy) }\end{array}$} \\
\hline & Ramp 2 - From Colombo & 134 & \\
\hline \multirow[t]{2}{*}{ Welipanna } & Ramp 1 - From Galle & 73 & \\
\hline & Ramp 2 - From Colombo & 69 & \\
\hline \multirow[t]{2}{*}{ Kurundugahahathakma } & Ramp 1 - From Galle & 45 & \multirow{5}{*}{$\begin{array}{c}\text { (Do not satisfy) } \\
\text { (Do not satisfy) } \\
\text { (Do not satisfy) } \\
\text { (Satisfy) }\end{array}$} \\
\hline & Ramp 2 - From Colombo & 134 & \\
\hline \multirow[t]{2}{*}{ Baddegama } & Ramp 1 - From Galle & 154 & \\
\hline & Ramp 2 - From Colombo & 90 & \\
\hline Pinnaduwa & Ramp 1 -From Colombo & 378 & \\
\hline
\end{tabular}

Table 11. Results and Proposals

\begin{tabular}{llcccc}
\hline Interchange & Direction & \multicolumn{3}{c}{ Failure reason at year } & Proposals \\
\cline { 3 - 5 } & $\begin{array}{c}\text { Longest } \\
\text { individual } \\
\text { delay at } \\
\text { year }\end{array}$ & $\begin{array}{c}\text { Maximu } \\
\text { m queue } \\
\text { length }\end{array}$ & $\begin{array}{c}\text { Minimum } \\
\text { deceleration } \\
\text { length }(169.04 \mathrm{~m} \\
\text { according to } \\
\text { WSDOT })\end{array}$ & \\
\hline Kottawa & 2035 & 2034 & 2034 exceeded & $\begin{array}{c}\text { At year 2034 ramp length has } \\
\text { to improve / Service rate has } \\
\text { to improve }\end{array}$ \\
\hline
\end{tabular}




\begin{tabular}{|c|c|c|c|c|c|}
\hline \multirow[t]{2}{*}{ Kahathuduwa } & $\begin{array}{l}\text { Ramp } 1 \text { - From } \\
\text { Galle }\end{array}$ & 2075 & 2075 & $\begin{array}{l}\text { Existing ramp } \\
\text { length not } \\
\text { enough }\end{array}$ & \multirow[t]{2}{*}{$\begin{array}{l}\text { Ramp length has to improve } \\
\text { from now }\end{array}$} \\
\hline & $\begin{array}{l}\text { Ramp } 2 \text { - From } \\
\text { Colombo }\end{array}$ & & & & \\
\hline \multirow[t]{2}{*}{ Galanigama } & $\begin{array}{l}\text { Ramp } 1 \text { - From } \\
\text { Galle }\end{array}$ & 2060 & 2050 & 2050 exceeded & \multirow{2}{*}{$\begin{array}{c}\text { At year } 2050 \text { ramp length has } \\
\text { to improve / Service rate has } \\
\text { to improve }\end{array}$} \\
\hline & $\begin{array}{l}\text { Ramp } 2 \text { - From } \\
\text { Colombo }\end{array}$ & & & & \\
\hline \multirow[t]{2}{*}{ Dodangoda } & $\begin{array}{l}\text { Ramp } 1-\text { From } \\
\text { Galle }\end{array}$ & & & $\begin{array}{l}\text { Existing ramp } \\
\text { length not } \\
\text { enough }\end{array}$ & \multirow[t]{2}{*}{$\begin{array}{l}\text { Ramp length has to improve } \\
\text { from now }\end{array}$} \\
\hline & $\begin{array}{l}\text { Ramp } 2 \text { - From } \\
\text { Colombo }\end{array}$ & 2040 & 2040 & & \\
\hline \multirow[t]{2}{*}{ Welipanna } & $\begin{array}{l}\text { Ramp } 1-\text { From } \\
\text { Galle }\end{array}$ & & & $\begin{array}{l}\text { Existing ramp } \\
\text { length not } \\
\text { enough }\end{array}$ & \multirow[t]{2}{*}{$\begin{array}{l}\text { Ramp length has to improve } \\
\text { from now }\end{array}$} \\
\hline & $\begin{array}{l}\text { Ramp } 2 \text { - From } \\
\text { Colombo }\end{array}$ & 2045 & 2045 & & \\
\hline \multirow[t]{2}{*}{ Kurundugahahatakma } & $\begin{array}{l}\text { Ramp } 1-\text { From } \\
\text { Galle }\end{array}$ & 2060 & 2050 & $\begin{array}{l}\text { Existing ramp } \\
\text { length not } \\
\text { enough }\end{array}$ & \multirow[t]{2}{*}{$\begin{array}{l}\text { Ramp length has to improve } \\
\text { from now }\end{array}$} \\
\hline & $\begin{array}{l}\text { Ramp } 2 \text { - From } \\
\text { Colombo }\end{array}$ & & & & \\
\hline Pinnaduwa & $\begin{array}{l}\text { Ramp } 2 \text { - From } \\
\text { Colombo }\end{array}$ & 2030 & 2030 & 2030 exceeded & $\begin{array}{c}\text { At year } 2030 \text { ramp length has } \\
\text { to improve / Service rate has } \\
\text { to improve }\end{array}$ \\
\hline
\end{tabular}

\section{Conclusions and Recommendation}

Southern Expressway will be directly influenced by additional traffic that would generate due to the anticipated rapid development of the Southern part of Sri Lanka. As seen from the study results, even at present, Kottawa and Pinnaduwa interchanges do not operate satisfactorily during long weekends and festive seasons. This study checked the effect of current toll gates on the free flow of the Southern Expressway. In fact, this study was conducted before commissioning the stretch from Pinnaduwa to Matara, and it is anticipated that the Pinnaduwa exit conditions will improve once the new stretch starts to operate.

It could be observed how each interchange dealt with maximum queue length, individual delay and minimum deceleration lane length. Table 11 indicates the years when exit ramp lengths will become insufficient for each interchange. Critical exit ramps of Kottawa (from Galle), Galenigama (from Galle), and Pinnaduwa (from Colombo) interchanges could cater to the traffic up to years 2034, 2050 and 2030 respectively. Kahathuduwa (from Galle), Dodangoda (from Colombo), Welipanna (from Colombo) 
and Kurundugahahatakma (from Galle) existing ramp lengths were selected without considering deceleration lane lengths. There is a tendency that vehicles begin to decelerate on the lane on expressway in advance of the off ramp lengths. This can affect the efficient and safe movements of traffic on the expressway. Therefore, it has to introduce an additional lane to allow for adequate ramp deceleration distances without disturbing the expressway through traffic. As an example, proposed layout plan for Kurundugahahatakma interchange shown in Figure 5. Table 11 shows that queue lengths will exceed the critical exit ramps in years 2034, 2075, 2050, 2040, 2045, 2050 and 2030 for the Kottawa (from Galle), Kahathuduwa (from Galle), Galenigama (from Galle), Dodangoda (from Colombo), Welipanna (from Colombo), Kurundugahahatakma (from Galle) and Pinnaduwa (from Colombo) interchanges respectively. Due to the spillback of the traffic queues from off ramps, capacity reduction of expressway is visible by bottlenecking the expressway.

The maximum individual delay of 10 minute duration exceeded in years 2035, 2075, 2060, 2040, 2045, 2060, 2030 for the Kottawa (from Galle), Kahathuduwa (from Galle), Galenigama (from Galle), Dodangoda (from Colombo), Welipanna (from Colombo), Kurundugahahatakma (from Galle) and Pinnaduwa (from Colombo) interchanges respectively.

Hence, the capacity of the Southern Expressway will get affected due to the inadequacy at toll gates unless the number of toll gates is increased or the efficiency of the toll collecting systems is improved, thus improving the efficiency of the toll gates which is more practical. Due to the operational procedure of electronic toll collection systems such as; automatic coin machines, touch and go systems, systems operated through transponders etc. the queue length and individual delay can be reduced. The service rates and operational procedure for above mentioned systems are indicated in Table 12. The last column of Table 12 presents the study proposals for toll gates. 
Table 12. Comparison of toll collection systems

\begin{tabular}{|c|c|c|}
\hline $\begin{array}{l}\text { Toll } \\
\text { collection } \\
\text { system }\end{array}$ & $\begin{array}{l}\text { Service } \\
\text { time (s) }\end{array}$ & Operational procedure \\
\hline $\begin{array}{l}\text { Manual toll } \\
\text { collection } \\
\text { system }\end{array}$ & 18 & $\begin{array}{l}\text { Cash toll is received by the collector. The collector, who also } \\
\text { dispenses change, may accept and sell scrip, tickets, } \\
\text { coupons, making an entry of the vehicle in the system and } \\
\text { issuing receipt to the patron. The processing time is highest, } \\
\text { due to manual intervention }\end{array}$ \\
\hline $\begin{array}{l}\text { Automated } \\
\text { coin machine }\end{array}$ & 5.20 & $\begin{array}{l}\text { These machines accept both coins and tokens issued by the } \\
\text { operating agency. Depending on the toll rate, the use of } \\
\text { automated coin or token collection instead of manual } \\
\text { collection reduces transaction and processing time as well as } \\
\text { the operating cost. }\end{array}$ \\
\hline $\begin{array}{l}\text { Touch and go } \\
\text { system }\end{array}$ & 3.50 & $\begin{array}{l}\text { The drivers are provided with a prepaid or postpaid card in } \\
\text { which the driver and vehicle details are been stored. And the } \\
\text { driver comes to the entrance has the card and the machine } \\
\text { reads the card information and sends it to the network. And } \\
\text { the gate is then opened. Also at the exit, when the driver } \\
\text { touches the machine with the card, the machine takes } \\
\text { necessary action to deduct the required amount of money. }\end{array}$ \\
\hline $\begin{array}{l}\text { Electronic } \\
\text { toll collection } \\
\text { system }\end{array}$ & 1.12 & $\begin{array}{l}\text { Most systems use the radio frequency transmitter and the } \\
\text { transponder in the vehicle for identification for the billing } \\
\text { process of electronic toll collection. It is mostly dealt by } \\
\text { banks, and the billing process can follow a post-pay over a } \\
\text { prepaid model. }\end{array}$ \\
\hline
\end{tabular}

(Source: www.researchgate.net)

Therefore, one of the tolling systems above described can be introduced to minimize the queue length and individual delay.

\section{References}

Banks, J. H. (2010), "Introduction to Transportation Engineering", $2^{\text {nd }}$ Edition, Tata McGraw-Hill, New Delhi, India.

Mannering, F. L. and Washburn, S. S. (2004), 'Principles of Highway Engineering and Traffic Analysis', 3rd edition, John Viley \& Sons, Inc, USA.

Mannaring, F. L. and Kilareski, W. P. (1998) "Principals of Highway Engineering and Traffic Analysis", 2nd Edition

Washington State Department of Transportation (2011), Design Manual, Washington, US.

www.rda.gov.lk/supported/expressways/stdp.htlm

www.researchgate.net

Received: 5-4-2015 Revised: 14-9-2015 Accepted: 15-9-2015 